NBER WORKING PAPER SERIES

TRUST IN PUBLIC FINANCE

Joel Slemrod

Working Paper 9187

http://www.nber.org/papers/w9187

\author{
NATIONAL BUREAU OF ECONOMIC RESEARCH \\ 1050 Massachusetts Avenue \\ Cambridge, MA 02138 \\ September 2002
}

This paper was presented at the conference Public Finances and Public Policy in the New Millennium, a celebration in honor of Richard A. Musgrave's $90^{\text {th }}$ birthday and the $10^{\text {th }}$ anniversary of CES held in Munich on January 12-13, 2001. I am grateful to Elizabeth Oltmans and Peter Katuscak for expert research assistance and extended conversations on the themes of this essay. I also thank two referees, David Bradford, Christopher Clague, Bruno Frey, Michael Burda, John T. Scholz, Daniel Shaviro and the participants at the New York University Tax Symposium and the Musgrave-CES conference for helpful comments on an earlier draft. The views expressed herein are those of the author and not necessarily those of the National Bureau of Economic Research.

(C) 2002 by Joel Slemrod. All rights reserved. Short sections of text, not to exceed two paragraphs, may be quoted without explicit permission provided that full credit, including $(\subset$ notice, is given to the source. 
Trust in Public Finance

Joel Slemrod

NBER Working Paper No. 9187

September 2002

JEL No. H10, P10, O40

\begin{abstract}
Using data on trust and trustworthiness from the 1990 wave of the World Values Survey, I first investigate a model of the extent of tax cheating and the size of government that recognizes the interdependence of the two. The results reveal that tax cheating is lower in countries that exhibit more (not-government-related) trustworthiness. However, holding that constant, tax cheating becomes more acceptable as government grows. All in all, there is some weak evidence that the strong positive cross-country correlation between the size of government and tax cheating masks the fact that big government induces tax cheating while, at the same time, tax cheating constrains big government.

I then add to the structural model an equation determining the level of prosperity, allowing prosperity to depend, inter alia, on the level of government and on trust in others. I find some evidence that both prosperity and government involvement are higher in more trusting societies. Moreover, holding these measures of trust constant, the association of government size with prosperity is positive until a level of government spending somewhere between $31 \%$ and $38 \%$ of GDP, after which its marginal effect is negative. Thus, although a trusting citizenry allows larger government, the tax burden this entails erodes the rule obedience taxpayers exhibit toward government.
\end{abstract}

Joel Slemrod

University of Michigan

A2120D Business School

Ann Arbor, MI 48109

and NBER

jslemrod@umich.edu 


\section{Trust in Public Finance}

\section{Joel Slemrod}

"Although good economic analysis calls for joint consideration of both [the expenditure and revenue sides], the practice is to deal with them as more or less separate issues." Musgrave and Musgrave (5th ed., p. 11)

"Some people are happy that there are externalities everywhere, and others would prefer that there be none at all." [paraphrased]

Richard Musgrave, on the occasion of receiving the honorary degree of Doctor of Laws from the University of Michigan, December 15, 1991.

\section{Introduction}

With a few exceptions, the positive and normative analysis of taxation has proceeded as if the purposes for which the funds are being raised and the efficiency if which they are utilized are irrelevant. As the first statement above makes clear, Richard (and, in this case, Peggy) Musgrave lamented this dichotomy. ${ }^{1}$ He argued that analytical blinders blurred important questions such as the net distributional impact of government and prevented fruitful discussion of policies such as the earmarking of revenues.

Throughout his career Professor Musgrave also took seriously the vital role government can play in an economy and a society, including but not limited to achieving an appropriate allocation of resources in the presence of externalities. In the second statement quoted above, he recognizes that not all people enjoy the interaction among people - the sense of community--that the presence of externalities compels. But clearly he himself does. He writes: "I think of the state as an association of individuals, engaged in a cooperative venture, formed to resolve problems of social coexistence and do so in a democratic and fair manner. And also: "Overrepresented in my German and

\footnotetext{
${ }^{1}$ Note that I am speaking here of why public finance theorists treat expenditures and taxation separately, and not about why in practice expenditure programs are not tied to particular tax instruments, the practice known as earmarking. Opponents of earmarking argue that it leads to a fragmented and inefficient tax system, and that tying expenditure amounts to specified tax revenues causes inefficient resource allocation decisions.
} 
underrepresented in my U.S. years, I am well aware that the concept of community is subject to abuse...At the same time, the concept of community should not be exorcised for that reason." (Buchanan and Musgrave 1999, pp. 31, 33)

In this essay I argue that the idea of community, fostered by trust among citizens and perhaps also by trust in government, ties together these two lifelong concerns of Professor Musgrave. Moreover, consideration of these issues may shed light on some important public finance issues, including whether taxpayers' evaluations of government expenditures or the fairness of the tax system affect their willingness to comply with the tax law, and whether variations in trust are an important factor in explaining the crosscountry patterns in levels of taxation and the type of taxes used. ${ }^{2}$

In what follows I first critically review some of the literature on trust among private parties and between citizens and government, and its implications for tax compliance behavior. Then, I discuss some empirical explorations into untangling the complex causal interactions between trust, government, and prosperity. I focus on whether trust in public finance can shed light on such longstanding questions such as Wagner's law, the effect of government on prosperity, and under what circumstances taxpayers act as free riders.

\section{Trust and Trustworthiness among Private Parties}

The notions of trust and the more recently coined term social capital have received much recent attention in social science, stimulated in part by the work of Putnam (1993) and Fukuyama (1995), but with antecedents in, for example, Coleman (1990). Economists have recognized the critical role played by trust in economic performance. Arrow (1972) has remarked that "virtually every commercial transaction has within itself an element of trust, certainly any transaction conducted over a period of time. It can plausibly be argued that much of the economic backwardness in the world can be explained by the lack of mutual confidence." In high-trust societies, individuals need to spend less resources to protect themselves from being exploited in economic

${ }^{2}$ The idea that the structure of the public finances can be instrumental in developing a sense of national community has a long history in the United States. Discussing Alexander Hamilton's plans to have the U.S. federal government assume the revolutionary debts of the states and combine them into existing federal debts, Sandel (1998, p. 134) says, "Fearful that local sentiments would erode national authority and 
transactions. Knack and Keefer (1997) argue that trusting societies tend to have stronger incentives to innovate and to accumulate both physical and human capital. Lack of trust in government may also have costs. Clague (1993, p. 412) argues that "a society with very low levels of rule obedience cannot...have a net of institutions that is conducive to economic progress."

The idea of reputation--the level of trust one is perceived to merit--has also been examined. As Axelrod (1986) puts it, an individual's reputation derives from adherence to or violation of a norm that others view as a signal about the individual's future behavior in a wide variety of situations. In Cripps and Thomas (1995), one establishes a reputation as others learn, in games with incomplete information, about one's propensity to use a particular strategy. Such reputation effects are common in multiple-player games modeling contributions to public good provision. For example, Marks and Schansberg (1997) find that providing the group with individual-specific information about past contributions partially offsets free riding.

Reputation also matters in interactions between individuals and firms. As explained by Campbell (1995), in a market economy, a firm has two sets of rivals: other firms and consumers. Competition with other firms keeps the return to capital low, so a firm must do years of business in order to pay off its initial expenditures on capital. This means that its strategy against consumers takes on a time dimension, as the firm relies on repeated interactions. The consumer's choice to "cooperate with," or buy from, the firm will then depend on whether the firm has "defected," or been misleading about its product, in the past. A firm's reputation, then, is simply the record of its past performance. The return to a firm's reputation comes in the willingness of others to enter into future incomplete contracts with the firm.

The flip side of trust is trustworthiness. Just as reputation is the ability to elicit trust from others, social capital — according to Glaeser et al. (2000) — is the ability to elicit trustworthiness from others. They distinguish between trusting behavior, which they define as "the commitment of resources to an activity where the outcome depends upon the cooperative behavior of others," and trustworthy behavior, which "increases the

doubtful that disinterested virtue could inspire allegiance to the nation, Hamilton saw in public finance an instrument of nation-building." 
returns to people who trust you." Glaeser et al. report the results of two experiments. The first operationalizes trust and trustworthiness as behavior in the two roles of a trust game in which the first player (the "sender," who is in a position to exhibit trusting behavior) is given $\$ 15$ and can choose how much of that to send to the second player (the "recipient," who is in a position to exhibit trustworthy behavior). The recipient receives, through the experimenters, twice whatever the sender sends, and then can choose how much to send back. In their second experiment, subjects report their willingness to pay for an envelope containing $\$ 10$ that is addressed to them and dropped in different public places; this experiment measures only trusting behavior.

One of their findings has important implications for evaluating much of the empirical research I discuss below. It turns out that the answer that their subjects gave to the survey question often used to measure trust in others in empirical studies--"Generally speaking, would you say that most people can be trusted or that you can't be too careful in dealing with people?"--correlates with trustworthy, but not with trusting, behavior. Moreover, high-status individuals tend to be trusting because their status induces people to act in a trustworthy manner toward them, ensuring a high return to trust. They suggest that much of the past research on individual behavior based on this and similar "trust" questions should therefore be reinterpreted, and conjecture that such questions are best used to predict "the overall level of trustworthiness in society." The distinction and relationship between trust and trustworthiness is important in the empirical analysis reported later.

\section{Trust and Government}

\subsection{Trust in Government}

What affects the relationship between citizens and the government has a quite different flavor than what affects relationships among private parties. The crucial difference is not the relative size of the two parties. After all, a consumer dealing with a large corporation is in the same relative size position as a citizen is in with respect to most federal governments.

What is unique to government is its role as the sole provider of public and other goods and services, its coercive power to collect taxes to pay for these goods and services 
and, critically, the absence of a link between what the citizen receives from government and what he or she pays to government. Firestone Tire Company wants to establish a reputation for a high-quality product because consumers need not buy its tires. Citizens, however, do not purchase public goods from government the way consumers purchase tires; the amount they pay in taxes does not determine the amount or quality of government services they receive. If, as the standard model of taxpayer behavior maintains, the perceived quality of government goods does not influence the level of taxes remitted, a government does not have a financial incentive to invest in its reputation for public goods production, since it will be unable to capture the return to such an investment. (It might, of course, have a political motive to do so.)

A more apt analogy is with a large charitable organization. As with government, any one person's contribution is a drop in the bucket and will not materially affect the organization's activities. Of course, unlike government, a charity cannot coerce (other than via peer pressure) donations. However, if one values what use the money is put to, then the donor or taxpayer might consider the donation to be a purchase rather than an exaction.

Note that there is at least anecdotal evidence that donors do respond to information about the trustworthiness of large charitable organizations. For example, after its national president was charged, and later convicted, of diverting charitable funds to his own use, the United Way, the premier fundraising organization in the United States, experienced a drop in donors and donations of about 20\%. (Johnston 1997). Moreover, there is considerable evidence that consumer purchasing decisions may depend on aspects of their perceptions of the producing company that are unrelated to the value-for-price tradeoff. The consumer boycotts of goods produced by Nike is a recent example. Kahneman, Knetsch, and Thaler (1986) discuss evidence that the response to a consumer good price increase will be more favorable if people judge the price increase to be necessitated by input cost increases rather than the desire for increased profits. Thus, even in the realm of purely private goods, some consumers may override their opportunistic impulses and be influenced by their approval of or trust in the producer.

The distinctive element of the relationship between taxpayer and government is the free-rider problem, also known as the zero contribution thesis. Because one's own 
outcome is unaffected by one's own "contribution," no one should voluntarily contribute to a public good--pay taxes--unless the threat of punishment makes it sensible. ${ }^{3}$ Thus, governments have a political, but not a financial, incentive to invest in their trustworthiness, and taxpayers have no incentive to be trustworthy toward the government, unless the enforcement regime makes it in their financial interest. ${ }^{4}$

It is undeniable that free riding behavior is ubiquitous. The story does not, though, end there. For example, a vast amount of experimental work (not to say anecdotal evidence) suggests that free-riding behavior is context-specific. Ostrom (2000, p. 140) remarks that the finding that "the rate of contribution to a public good is affected by various contextual factors" is one of seven phenomena that "have been replicated so frequently that these can be considered the core facts that theory needs to explain." The challenge, then, is to identify aspects of government expenditure and tax policies that mediate the free rider impulse in an empirically important way.

Although trust in other people and trust in government are not the same thing, they may be related. Brehm and Rahn (1997) argue that confidence in government may be partly a reflection of the more general relationship of trust in people--if people are untrustworthy in general, then people in government are untrustworthy as well. Of course, as Brehm (1998) points out, taxpayers may not see people in government as being ordinary people, perhaps because they believe that being in government creates opportunities for people to exploit others that are not available to ordinary people.

Furthermore, confidence in government can be a positive force in trusting others, in part because government can act as a safeguard for our willingness to extend trust to others. Establishing a fair and efficient legal system is the best example of this, but there are others. Fukuyama (1995) stresses the role of government in lowering the personal investments and providing the assurances that make possible the trust that lubricates cooperation. On the other hand, some argue that the centralized state undermines cooperation and destroys trust among individuals. Taylor (1982) argues that the

\footnotetext{
${ }^{3}$ The same argument, of course, applies to other decisions such as whether one should anyone expend the time and effort to vote.

${ }^{4}$ Note that citizens cannot invest in reputation by being trustworthy towards government. Tax compliance lacks the characteristic - vital to building reputation by signaling trustworthiness — of being observable. In only the rarest cases, after all, is one's tax evasion made publicly known.
} 
centralized state drives out spontaneous coordination that depends on small groups and "thick" networks of interaction.

\subsection{Trustworthiness and Reputation of Government}

In a competitive political system such as a democracy, governments face incentives to establish good reputations in order to encourage the electorate to select them rather than their rivals in the future. Moreover, to the extent that capital is mobile, governments with good reputations for cooperating with business will find that more businesses choose their country in the future.

The role of government reputation and credibility has been extensively examined, most often in the context of monetary policy (e.g., Barro and Gordon 1983), but reputation has also been used to interpret actors' responses to other sorts of government policies. For example, Epple (1998) discusses local government reputation with respect to whether a town will continue a no-rent-control policy if it is not bound to do so, and the choices that property owners make that are dependent on that reputation.

In these situations, it is in individuals' interest to evaluate whether commitments made by the government are credible. The question on the table is, though, quite different--whether trust in government can cause citizens to abandon their short-term financial interest of free riding. In this context, Levi (1998) argues that citizens are likely to trust government only to the extent that they believe that it will act in their interests, that its procedures are fair, and that their trust of the state and others is reciprocated. She argues that government trustworthiness, plus the perception that others are doing their share, can induce people to become "contingent consenters" who cooperate even when their short-term material self interest would make free riding the individual's best option. She writes that "the willingness to pay taxes quasi-voluntarily or to give one's contingent consent to conscription often rests on the existence of the state's capacity and demonstrated readiness to secure the compliance of the otherwise noncompliant." (Levi 1998, p. 91)

The operating definitions of trustworthiness of government and trust in government that I will adopt are in the spirit of Levi. Government trustworthiness is all those actions that may induce people to forego their opportunistic behavior and become contingent compliers. Trust in government is a belief that the government is carrying out 
those actions. The first two aspects of this trust do not depend on the reciprocal actions of other citizens, and in these cases trust is close to "approval." The third aspect--the perception that others are doing their share--is more closely related to the notions of trust in others that I have already touched on, because it is about whether people act as if others will follow through on what they have promised to do. Clearly, the survey questions on which the empirical investigations that follow rely do not precisely correspond to these definitions; they are, though, close enough to be worth examining.

\section{Trustworthiness of Taxpayers: Tax Compliance}

With regard to free rider behavior toward the government, tax compliance poses the foremost temptation. Although officially the U.S. income tax system is based on voluntary compliance, ${ }^{5}$ in one sense that characterization is purely Orwellian. An elaborate system of employer withholding, matching of information reports, and audits with penalties for detected evasion "encourages" compliance. The fact that, line item by line item, there is a clear positive correlation between the so-called voluntary compliance rate with the U.S. income tax and the presence of these enforcement mechanisms confirms their importance. ${ }^{6}$

Some have argued, however, that the idea of voluntary compliance is not just Orwellian Newspeak. The argument is sometimes loosely based on the observation that, given the probability of audit and the penalties typically assessed, evasion seems to be a winning proposition for many more people than actually do evade. For example, Feld and Frey (2000, p. 5) assert that it is "impossible to account for tax compliance in terms of expected punishment." From this perspective, the puzzle is not to explain why people

\footnotetext{
${ }^{5}$ The IRS Mission Statement, as cited in Steuerle (1986, p. 1) lists as its first task to "encourage and achieve the highest degree of voluntary compliance in accordance with the tax laws and regulations." IRS measures of the level of tax compliance are all couched in this language, featuring concepts such as the "voluntary" reporting percentage, and "voluntary" compliance level.

Some tax protestors in the United States have used references in court cases to the voluntary nature of taxes as a justification for non-payment. A quotation frequently cited is the following by the U.S. Supreme Court: "Our tax system is based upon voluntary assessment and payment and not upon distraint." Flora v. United States, 362 U.S. 145, 175. This quotation is taken out of context, and other courts' statements make clear that the opposite is true, such as: "Any assertion that the payment of income taxes is voluntary is without merit. It is without question that the payment of taxes is not voluntary." United States v. Gerads, 999 F.2d 1255, 1256 (8th Cir., 1993), per curiam). These quotations are collected in "The Tax Protestor FAQ," created by Daniel Evans, http://evans-legal.com/dan/tpfaq.html.

${ }^{6}$ See Klepper and Nagin (1989).
} 
evade, but rather why people pay (so much) taxes. Solutions to this puzzle generally require pushing beyond the standard economic model, in the context of which people who voluntarily comply are exhibiting nothing short of "pathological honesty."

I discuss below these attempts to solve the puzzle of apparently voluntary, or pathological, compliance. Before doing so, I must record my objection to the proposition that the standard economic model of tax evasion, due to Allingham and Sandmo (1972), has been discredited. The dismissive argument runs along the following lines. The average audit rate in the U.S. is less than $2 \%$. With that probability of evasion being detected, and with the penalty rates in effect, what we know about the degree of risk aversion from other contexts suggests that compliance should be much, much lower than it apparently is. The flaw in this argument is that the $2 \%$ probability of detection is certainly a vast understatement for the bulk of income subject to tax. A wage or salary earner whose employer submits this information electronically to the Internal Revenue Service, but who does not report that income on his own personal return, will be flagged for further scrutiny with a probability much closer to $100 \%$ than to $2 \%{ }^{7}$

Thus, this simple argument for the failure of the utility-maximization approach itself fails. There is, though, some other evidence. I have already referred to the experimental evidence, such as Spicer and Becker (1980) and Alm, Jackson, and McKee (1992), in which subjects respond not only to the probabilities and stakes of a tax evasion game, but also to context provided to them. In contrast, Mason and Calvin (1984), in an analysis of survey data in Oregon, found that dissatisfaction with the tax system is no directly related to reported noncompliance, although it changes other attitudes and beliefs. Cowell (1990, p. 219) reports on other experimental evidence that fails to find links between perceived inequities in the tax system and non-compliance. Kaplan and Reckers (1985) found that beliefs about tax morality were more important than beliefs about the tax fairness of the tax system.

Also worthy of note is the ambitious recent attempt of Scholz and Lubell (1998) to examine if trust in government affects tax compliance using data from a one-hour inperson survey supplemented by tax return data. They have no direct measure of

\footnotetext{
${ }^{7}$ In addition, to the extent that past years' returns may be audited, the relevant probability is the probability of audit over a number of years rather than in a single year.
} 
noncompliance, but use instead a measure based on answers to twelve questions about compliance over a three-year period with specific sources of income, general income, deductions, and overall tax reporting. Their measure of trust in government is the summed response to two questions: "You can generally trust the government to do what is right," and "Dishonesty in government is pretty rare." To measure trust in citizens, they use the survey answers to "what percentage of taxpayers at your income level...pay less taxes than they legally owe." 8 Scholz and Lubell argue that the amount of benefits from public activities depends on the amount of taxes collected, which in turn depends on the fraction of honest taxpayers, so that greater trust measured in this way should correspond to a belief in greater benefits from the collective. This reasoning requires a set of tenuous assumptions, and may be related to noncompliance as a rationalization.

Scholz and Lubell also control for attitudes about tax fairness and equity, civic duty, political efficacy, tax duty, opportunity for evasion, and being in a high noncompliance occupation. With these controls, they find that high scores on both trust measures significantly decrease the likelihood of noncompliance. Surprisingly and apparently contradictorily, political efficacy (whether the respondent has a "say" in what the government does and whether it is run "mainly for the benefit of special interests") increase noncompliance. The authors rationalize this finding by suggesting that political efficacy may lead to a perceived ability to manipulate the system without risk.

Because of several methodological weaknesses, the Scholz-Lubell study is far short of being definitive. Overall, there is no compelling evidence to discard the Allingham-Sandmo model of tax compliance, but there are also compelling reasons to believe that free riding in other areas is suppressed, and that tax evasion free riding is suppressed in experimental situations-- to take seriously that tax compliance does respond to taxpayers' attitudes toward government. ${ }^{9}$

\footnotetext{
${ }^{8}$ This latter question is obviously much different from the trust question used in most of the other studies discussed below.

${ }^{9}$ Victor Hugo, in Les Miserables, observed the following relationship between tax compliance and prosperity in 18th Century Paris:

"When the population suffers, when work is lacking, when there is no commerce, the tax-payer resists imposts through penury, he exhausts and oversteps his respite, and the state expends a great deal of money in the charges for compelling and collection. When work is abundant, when the country is rich and happy, the taxes are paid easily and cost the state nothing. It may be said, that there is one infallible thermometer of the public misery and riches; the cost of collecting the taxes." (Penguin Classic edition, p. 171)
} 
In their review of tax compliance research, Andreoni, Erard, and Feinstein (1998) identify three classes of explanation for why observed evasion is apparently lower than conventional economic models of tax evasion predict: moral rules or sentiments that determine the psychic costs of evasion, evaluations of the fairness of the tax code and its enforcement, and evaluation of government expenditures and corruption. Frey (1997) links the first two classes of explanation by differentiating between intrinsic and extrinsic motivation. With intrinsic motivation, taxpayers pay because of "civic virtue;" with extrinsic motivation, they do so because of threat of punishment. Frey argues that increasing extrinsic motivation - say with more punitive enforcement policies-"crowds out" intrinsic motivation by making people feel that they pay taxes because they have to, rather than because they want to. ${ }^{10}$ Similarly, in Cullis and Lewis (1997), individuals care not only about their own consumption, but also value their own compliance with the social convention of tax compliance and separately the extent of others' compliance with the norm, either directly or indirectly via pecuniary consequences. Falkinger (1995) argues that if tax equity strengthens the social norm against evasion, then evasion becomes more costly in terms of bad conscience (if not caught) or bad reputation (if caught) in a society with a more equitable system. Moreover, as Andreoni et al. point out, perceived unfairness can be used to rationalize evasion in one's self-interest, thereby decreasing psychic costs.

In Bordignon (1993) there is a relationship between the individual and the government that involves exchange rather than mere coercion. The taxpayer computes the terms of trade between his private consumption and the government provision of public goods, and evades (up to his level of risk aversion or up to the level he feels reestablishes fairness) if he finds these terms unfair. Unfairness in this model reflects either an inadequate level of goods provision with respect to the required tax payment, an unfair tax structure, or evasion by other taxpayers. Andreoni et al. add that an individual can also find unfairness in goods provision due to the provision of the wrong goods-i.e.,

Note that this behavior would produce a Wagner's Law phenomenon in which tax collections as a fraction of income are higher when income is higher. I am grateful to Jonathan Skinner for bringing this quotation to my attention.

${ }^{10}$ Scholz and Lubell (2001), in an experimental setting, find that the level of cooperation in certain settings declines significantly when penalties are introduced, suggesting that the increased deterrence motivation did not compensate for the change in decision frame brought about by the penalties. 
someone such as Thoreau may avoid taxes because he thinks government policy wrong. But, as Daunton (1998) points out, this is not a simple matter. Expenditures on warfare might be tolerated in a patriotic period but rejected during another period characterized by anti-militarism. Expenditure on welfare might at times be seen as a socially desirable pooling of risk, and be seen at other times as a source of national decay.

Feld and Frey (1999) link all three ideas with what they call a psychological contract between the tax authority and citizens, which they believe is the model that describes taxation in areas with high levels of direct, rather than merely representative, democracy. They argue that where the relationship between the individual and the tax authority is seen as involving an implicit contract sustained by trust, individuals will comply due to high "tax morale." To sustain citizens' commitment to the contract and therefore their morale, the tax authority must act respectfully toward citizens while at the same time protecting the honest from the free rider. It does this by giving taxpayers the benefit of the doubt when it finds a mistake, by sanctioning small violations more mildly, and by sanctioning large and basic violations (e.g., the failure to file a return) more heavily. In a study of local governments in Switzerland, they find that these policies are in fact used more in more direct democracies.

They claim that such contracts are stronger-and therefore the authority relies on the above techniques more heavily — in direct democracies for several reasons. First, citizens in these areas have selected (or at least, Feld and Frey assume, felt comfortable with the selection process of) the programs that their taxes support, and therefore should feel more willing to pay for them (this assumption falls in line with Andreoni et al.'s third idea). After all, they can express discontent with either tax or spending policy by changing the laws, so they don't need to rely on a violation of the psychological contract. Since the authority knows this, it feels justified in treating citizens as trustworthy.

Of course, an alternative theory could be that in a direct democracy, citizens simply choose tax policies that involve respect because they prefer them, rather than that there is a psychological contract in place that makes such policies the most efficient way of collecting taxes. However, Feld and Frey's finding that blatant violations of the tax code are punished more heavily in direct democracies does provide some evidence that 
citizens in more direct democracies are not simply pushing for leniency but rather evaluating behavior as upholding or violating a basic contract.

Whether we call this behavior pathological honesty, or alternatively, good citizenship, the fact is that the cost of raising taxes, and of running the government, is lower to the extent that taxpayers "volunteer" to comply. It is as if there is a stock of goodwill, or social capital, the return to which is the more efficient operation of government. This social capital stock may be reduced by a policy change that decreases the incentive to be a law-abiding citizen.

It is interesting to note that all of the literature about whether attitudes affect compliance applies to individual taxpayers, although in most countries the bulk of taxes are remitted (as opposed to borne, in the sense of ultimate incidence) by businesses, either because the taxes are levied on business entities or because labor income taxes are withheld by the employer. Whether a company's policy would react as an individual is a fascinating and completely open question, one that is related to the motivations behind corporate charitable contributions. ${ }^{11}$

Paying taxes in excess of the remittance that is one's utility-maximizing interest can be considered a voluntary contribution to government. ${ }^{12}$ There is a more direct way to make such contributions--just send money. ${ }^{13}$ In the United States, people have always been able to do this, but since 1961 Congress has allowed people to earmark contributions for reducing the national debt, and has kept records on the amount of contributions. Moreover, since 1982 the Internal Revenue Service has included instructions in its tax packet on how to make such a contribution. In the fiscal year 2000, these contributions totaled $\$ 1.855$ million, which amounts to about $0.00001 \%$ of federal tax collections in that year and about $0.0008 \%$ of financial contributions to charities. Less than $10 \%$ of these gifts are included with federal tax returns. In fiscal year 1996,

\footnotetext{
11 See, e.g., Clotfelter (1985).

${ }^{12}$ The tax payments, or lack thereof, of some taxpayers may reflect "pathological dishonesty," if they underpay compared to their rational utility-maximizing calculus because of their aversion to government.

${ }^{13}$ Some fraction of purchases of U.S. Savings Bonds might be considered to be a contribution to the government, to the extent that the return-for-risk is lower than a non-government alternative, and this is known to the purchaser.
} 
366 Americans slipped checks totaling just $\$ 85,378$ to reduce the federal debt inside their tax returns. ${ }^{14}$

Slemrod and Oltmans (2000) investigates the aggregate annual amount of such gifts since 1961, to see if their magnitude is systematically related to attitudes toward government or objective measures of government expenditure patterns, tax structure, and the deficit. They do discover such relationships. For example, gifts to government are higher in years when the national debt is higher, suggesting a need-driven motive for gifts. Perhaps surprisingly, gifts are higher when the proportion of the population who endorse the belief that government wastes taxes is higher. This is consistent with donors embracing the earmarked nature of the gift--to a good use, reducing the debt, rather than a bad use, wasteful government spending. More generally, the systematic nature of these gifts is consistent with the notion that the gifts implicit in extraordinary tax compliance levels may also be related to attitudes and objective measures of government expenditure, taxation, and deficit policies.

\section{Previous Literature on the Relationship between Trust, Government and Prosperity}

It is one thing to hypothesize about the role of trust in government in taxpaying behavior and the efficient operation of an economy. It is quite another, and more demanding, task to identify its role empirically. This section briefly reviews some of the existing literature related to that task, while the next section presents research that extends our empirical knowledge of the inter-relationship within and, mostly, across countries.

\subsection{Evidence on the Determinants of Taxation and Government Spending}

Trust and social capital may provide a clue to explaining one of the most striking empirical regularities in public finance -- the positive association between a country's

\footnotetext{
${ }^{14}$ There are also fascinating localized examples of gifts to government. For example, in 2000 the state of Pennsylvania mailed out 2.5 million income tax rebates to its taxpayers; the rebate was prompted by a large budget surplus, and was described as an offset to local property taxes. The Associated Press (2000) reports that hundreds of these checks have been signed over to local school districts. One donor was quotes as saying that "it's important that schools have more money to meet their needs."
} 
tax-to-GDP ratio and its level of affluence, as measured for example by its per capita GDP. Two classes of explanation have been offered to explain this association. ${ }^{15}$ The first, called Wagner's Law, is a demand explanation. It posits that rising incomes and associated structural changes (such as urbanization) engender a demand for more government involvement. Another explanation is that affluence is associated with demographic characteristics (such as literacy and less reliance on agriculture) that facilitate raising tax revenue, which in turn leads to expanded government activity. Of course, these explanations are not mutually exclusive, and the research challenge, as in many settings, is to disentangle the supply and demand explanations for government expenditure and taxation. ${ }^{16}$

Professor Musgrave, in his 1969 book Fiscal Systems, noted the high positive correlation, both across countries and over time, between GDP per capita and the total tax ratio, as did Richard Goode (1968). Goode suggests that rather than income being the driving factor, this correlation may result from the positive correlation between per capita income and other social and economic conditions that make direct taxes acceptable and effective, such as a high level of literacy, wide use of standard accounting methods, effective public administration, and political stability. Musgrave himself noted that the relationship between income and the tax ratio is solely a result of comparing low and high-income groups of countries, and did not hold within each group of countries. More recently, Tanzi (1992) investigates the determinants of the share of tax in GDP in 83 developing countries during the period 1978-1988. He finds that, by itself, the log of per capita income is positively associated with the tax ratio, but the share of agricultural output in GDP (highly negatively correlated with per capita GDP) explains more of the variation in tax shares than does per capita income and has a negative sign. When both variables are included, per capita income no longer has a significant positive effect, although the negative effect of the agricultural share survives.

\subsection{Evidence on the Effect of Trust (and Government) on Prosperity}

\subsubsection{Trust}

\footnotetext{
${ }^{15}$ By the way, the same relationship holds for most countries over time: the tax-GDP ratio has grown as the country has become richer.

${ }^{16}$ See Slemrod (1995) for the problems involved in this enterprise.
} 
There is some empirical evidence that trust and civic duty among a country's citizens contribute to growth. ${ }^{17}$ Knack and Keefer (1997) tested the impact of these attitudes on both growth and investment rates in a cross-section of 29 countries, using measures of trust and civic norms from the World Values Surveys of 1981 and 1990. To assess the level of trust in others in a society, they use the WVS question investigated above. The strength of norms of civic cooperation was assessed from attitudes toward five particular actions, including the tax evasion question used here already.

Knack and Keefer find that social capital variables exhibit a strong and significant positive relationship to economic growth. As they note, the causality of this relationship could go in either direction: trust could be a product of optimism generated by high or growing incomes, or it could be that trust facilitates prosperity. However, they find that trust is more correlated with per capita income in later years than with income in earlier years, suggesting that the causation runs from trust to growth more so than vice versa.

One possible channel through which trust might affect economic outcomes is its impact on the performance of government. To investigate this, Knack and Keefer construct an index of how much confidence people profess in various governmental and societal institutions and find that, controlling for per capita income and education enrollments, the only significant determinant of government performance is the trust variable: a trusting citizenry facilitates a successful government. It is, though, conceivable that the causation is reversed -- that it is the behavior of governments that influences levels of trust.

Zak and Knack (2001) extend the Knack and Keefer framework by separately testing for the effect on growth of proxies for the presence of formal institutions, social distance, and discrimination and for whether their effect remains significantly correlated with growth controlling for measures of trust. They find that trust is positively and significantly related to growth even in the presence of measures of formal institutions or of social distance, but that most of the influence of the latter on growth occurs through their impact on trust. The one exception is a measure of property rights, which retains its independent positive association with growth even in the presence of a trust variable.

\footnotetext{
${ }^{17}$ There is also an older literature of cross-country research on national development that argued that nations whose people generally support government policies progress more rapidly than nations in which obedience must be coerced. See Almond and Verba (1963).
} 
They justify this finding by noting that this index includes government actions against private agents. In contrast, the trust measure is "likely to be little affected by perceptions of the trustworthiness of government...” (p. 316)

La Porta, Lopez-de-Silvanes, Shleifer, and Vishny (1999) find that, across countries, a one-standard deviation increase in the measure of trust increases judicial efficiency by 0.7 of a standard deviation and reduced government corruption by 0.3 of a standard deviation. Putnam (1993) examines cross-regional Italian data and concludes that local governments are more efficient where there is greater civic engagement.

\subsubsection{Government}

In recent years there has been an explosion of cross-country studies of the impact of government taxation and expenditure on prosperity. In contrast to the literature on the determinants of the size of government discussed above, and to the new analyses

presented later, the prosperity indicator in all these studies is a measure not of the level of prosperity, but rather of its rate of growth

In the most influential of these studies, Barro (1991a) examines a cross-section of 98 countries for the period 1960-1985 and, among other concerns, investigates the impacts on economic growth of government expenditures, measured as the ratio to real GDP of real government consumption purchases less spending on education and defense. He finds a significantly negative association of this government expenditure variable, averaged over the period 1970-1985, with real growth from 1960 to 1985. Barro suggests that one interpretation of these findings is that government consumption introduces distortions, such as high tax rates, but does not provide an offsetting stimulus to investment and growth.

Several subsequent studies, most notably Levine and Renelt (1992) and Easterly and Rebelo (1993) have, however, demonstrated that this negative association is by no means robust to reasonable alternative formulations. Easterly and Rebelo (1993), using several different measures of fiscal policy, find that measures of the level of taxes tend to be insignificant in Barro-style growth rate regressions. They ascribe this finding to the strong positive correlation between their fiscal variables and the initial (1960) level of per capita income, making it difficult to disentangle the effects of fiscal variables from those of the initial level of income--the "convergence" effect discussed in Barro and Sala-i- 
Martin (1992) and elsewhere. Slemrod (1995) reviews this literature and concludes that it has not resolved many of the problems with interpreting the estimated coefficient of a $\mathrm{G}$ variable in a growth equation.

\section{New Evidence on the Structural Relationship Among Trust, Government and Prosperity}

Although there is a growing and, in some cases, large empirical literature on the determinants of growth, size of government, and aspects of trust and trustworthiness, it is fair to say that no empirical analysis has attempted to untangle the structural relationships among them. This section begins that task. As is inevitable for a first step, it leaves many open questions. Nevertheless, it is promising in that the data analysis is supportive of several of the hypotheses raised earlier in this paper.

\subsection{Data}

The data on trust and trustworthiness come from the 1990 wave of the World Values Survey (WVS), the purpose of which is to facilitate cross-national comparisons of values, norms, and attitudes. The survey was conducted, with limited national modifications, in 45 countries. It asked about attitudes concerning work, family, religion, politics, and contemporary social issues and gathered a limited amount of demographic data as well. The 25 capitalist countries in the survey for which sufficient other data are available make up my sample. ${ }^{18}$ Although the data are subject to the usual reservations about attitude surveys, and in particular cross-country attitude surveys, the data has been widely and fruitfully used by political scientists and sociologists, not to mention Knack and Keefer (1997) and Zak and Knack (2001); for an extensive, albeit incomplete, list of its use in research, see Inglehart, Basanez, and Moreno (1998).

Along with other variables that are used in the analysis (for a description, see the Data Appendix), I will use three WVS variables as indicators of trust and trustworthiness. These come from the following questions:

\footnotetext{
${ }^{18}$ The countries are Argentina, Austria, Belgium, Canada, Chile, Denmark, Finland, France, (West) Germany, Iceland, India, Ireland, Italy, Japan, (Republic of) Korea, Mexico, Netherlands, Norway, Portugal, Spain, Sweden, Switzerland, Turkey, the United Kingdom, and the United States.
} 
Generally speaking, would you say that most people can be trusted or that you can't be too careful in dealing with people?

Please tell me whether you think that lying in your own interest can always be justified, never be justified, or something in between. (scale from $1=$ never justified to $10=$ always justified)

Please tell me whether you think that cheating on tax if you have the chance can always be justified, never be justified, or something in between. (scale from $1=$ never justified to $10=$ always justified)

The weighted mean values are used as country-level measures of trust in others, (lack of) trustworthiness, and acceptability of tax evasion, respectively. ${ }^{19}$ The responses are rescaled to lie in a 0 to 100 range.

\subsection{Correlations, Without Causation}

As background for the empirical exercises, Tables 1 and 2 present correlation matrices. (Summary statistics are presented in Tables 4 and 5). Table 1 refers to withincountry responses for the United States and West Germany. Among respondents from each country, trust in others is positively associated with both financial satisfaction and income. The story is slightly different for tax evasion as a measure of trustworthiness. The acceptability of tax evasion falls with financial satisfaction in both countries, but increase with income in Germany and, although not with statistical significance, in the United States. Trustworthiness as measured by refraining from lying is also positively correlated with financial satisfaction, but negatively associated with income. This suggests that the attractiveness of opportunistic behavior follows a "satisficing" pattern: people of any income who are satisfied with their lot are more likely to abstain from this kind of behavior.

There is also generally a clear positive association between trust in others and the two measures of trustworthiness. By far the highest correlation is between the two measures of trustworthiness ("is lying ok" and "is tax evasion ok?"), suggesting that whatever mechanism inculcates these norms affects both one's behavior towards people

\footnotetext{
${ }^{19}$ I also ran the same set of models using unweighted country means from the World Values Survey data. The results are very similar both qualitatively and quantitatively to those reported here.
} 
for whom establishing a reputation may have a payoff and one's behavior toward the government, for which it is unlikely to have a payoff in the private sector. However, in both countries those who trust or have confidence in government are less likely to find tax evasion acceptable. ${ }^{20}$

In both countries more educated people are more likely to trust others, but are also more likely to find lying and, in Germany only, tax evasion to be acceptable. They exhibit less confidence in government. Religious people are on average both more trusting and, particularly, more trustworthy. Those on the right of the political spectrum have less trust in others in the U.S. but not significantly in Germany and, perhaps surprisingly, have more trust in government in the U.S.. In the U.S., those with a rightwing political orientation are neither more nor less trustworthy on average to a significant degree; they are clearly more trustworthy in Germany.

The positive correlation in the U.S. between trust in others and trust in government is consistent with the finding of Brehm (1998), who argues based on the 1996 National Election Survey data from the United States that there is a strong positive relationship between social trust and government trust. However, Newton (1999) shows that the positive correlation between trust in others and trust in government is not a general result. He finds that among 12 countries in the 1990 World Values Survey that have both questions, the correlation between trust in government and trust in others is small and a negative .03. Newton concludes that political trust is not caused so much by social or economic factors as by political ones, including the record and orientation of the party in power; for example, right-leaning people will be more likely to express distrust when the left is in power. Newton (1999) does, though, find that the positive correlation of social trust with satisfaction with life, age, religiosity, income, and education level is quite robust across seven developed countries.

Table 2 is a weighted correlation matrix of the country means of the measures of trust, the measures of trustworthiness, and other country-specific indicators. Because the number of observations is so much lower, the significance levels are on average much

\footnotetext{
${ }^{20}$ The trust in government question ("How much do you trust the government in [national capital] to do what is right?") was asked in only 7 of the 25 sample countries, so it is unfortunately not used in the analysis that follows.
} 
lower compared to the within-country correlations of Table 1, although the correlations themselves are often much higher in absolute value.

Across countries trust in others is still strongly a phenomenon of affluence. However, the relationship between financial satisfaction and evasion flips sign in the cross-country context. While within the U.S. and Germany those who profess to be more financially satisfied are less likely to condone evasion, across countries more financial satisfaction is positively correlated with condoning evasion. Across countries, the correlation between trust in others and the acceptability of evasion reverses sign and become positive, although the statistical significance is not strong. It is also true that across countries the relationship between either religion or political orientation changes notably. Although within the U.S., religious people are both more trusting and trustworthy, across countries the opposite is true for trust in others, and no clear relationship exists for the other measures.

For later purposes, one further set of correlations is worth noting. In countries with a high level of government involvement, people are more likely to find tax evasion to be acceptable, even though their residents are not notably less trustworthy generally (as measured by their response to the question about the acceptability of lying in one's own interest), and are significantly more trusting of others. In fact, the highest absolute correlants with evasion attitudes, other than the other measure of trustworthiness, are measures of the country's level of government.

\subsection{A Structural Model}

\subsubsection{Tax Cheating and Size of Government}

I begin by investigating a model of the extent of tax cheating and the size of government that recognizes the interdependence of the two. In what follows I use $\mathrm{G}$ to denote the extent of government involvement in the economy, TC to denote attitudes toward tax cheating, TW to denote trustworthiness, and TO to stand for trust in others. Finally, Y will denote a measure of prosperity, measured by the log of GDP per capita.

The two structural relationships are summarized as follows:

(1) $\mathrm{TC}=\mathrm{TC}(\mathrm{G}, \mathrm{TW}, \mathrm{ZTC})$

(2) $\mathrm{G}=\mathrm{G}(\mathrm{Y}, \mathrm{TC}, \mathrm{ZG})$ 
Equation (1) refers to the determination of attitudes toward tax cheating. It is presumed to depend on the degree of overall trustworthiness in the society, assumed to be exogenous in this analysis, and on the extent of government involvement and the tax burden. The only other exogenous variable is the average age of the survey respondents. ${ }^{21}$ In other studies, age has been found to be negatively associated with the propensity to evade taxes.

Equation (2) represents the determination of the extent of government involvement in a country. This may depend, via Wagner's Law, on the level of prosperity. I hypothesize that it also depends on the extent to which people are willing to suspend their free-rider impulses and forego tax cheating opportunities; the more people do so, the lower is the cost of raising resources for government, and the larger government will be. Included in the vector of explanatory variables, ZG, are standard indicators of either the demand for or cost of providing government services. In particular, ZG includes the age dependency ratio, the percentage of the economy that is agricultural, the extent of illiteracy, and the extent of openness. Some of these variables may affect the size of government both via the cost of raising revenue and the demand for government services, so that the interpretation of these variables' coefficients is problematic. Finally, in ZG is a dummy variable for whether the country's legal system is of either English, Scandinavian, or German (but not French) origin. Following La Porta, et al (1999) this variable may represent a historical tradition of limiting government power.

The results of estimating this system using three-stage least squares ${ }^{22}$ are shown as Model 1 of Table 3. The equation explaining attitudes toward tax cheating is crisp and reasonable. It says that tax cheating is lower in countries that exhibit more (notgovernment-related) trustworthiness. However, holding that constant, tax cheating

\footnotetext{
${ }^{21}$ Holding trustworthiness constant, elderly people may have different attitudes toward evasion because they may have less direct involvement with the income tax system.

${ }^{22}$ Joint significance tests on the slope coefficients in each of the first-stage instrumenting regressions were carried out in each of the three models considered. After adjusting the estimated variance matrices by the White heteroscedasticity correction, each of the tests displays significance at a $1 \%$ level, except for the equations for $\mathrm{G}$ and $\mathrm{G}$-squared in Model 3, which are significant at a $5 \%$ level.
} 
becomes more acceptable as government grows, to a significant and larger degree. An older population reduces the average acceptability of tax evasion.

The second column of Model 1 shows the results of estimating a structural equation explaining the level of government. There is clear evidence of a Wagner's Law relationship, as evidenced by the significant and large coefficient on the log level of income. Holding income (and the ZG variables) constant, though, a more accepting attitude toward tax cheating does limit the size of government. True, the estimated relationship does not reach standard levels of statistical significance. Nevertheless, there is some weak evidence that the strong positive correlation between the size of government and tax cheating masks the fact that big government induces tax cheating while, at the same time, tax cheating constrains big government. Certainly, more research is needed to clarify this structure.

Among the exogenous variables, the openness measure is significantly positive, corroborating the findings of Rodrik (1998) and Cameron (1978) before him. The illiteracy variable is also positive, suggesting that it serves more as a measure of the demand for social services than as a measure of the difficulty of raising revenue. Neither the age dependency variable nor the agriculture variable is significant. The legal system dummy variable does enter as hypothesized, in that an English, German or Scandinavian system of law is associated, although not significantly at conventional levels, with smaller governments than otherwise.

\subsubsection{Tax Cheating, Size of Government, and Prosperity}

I next expand the ambitiousness of this exercise by adding to the structural model an equation determining the level of prosperity, equation (3) below. In its structural equation, I allow prosperity to depend on the level of government (and the level squared, to allow that the marginal impact can change sign at a certain level), on trust in others (as emphasized by Knack and Keefer (1997) and others), and a short vector of exogenous variables. The two exogenous variables measure the physical capital stock (specifically the capital-labor ratio) and the human capital stock (measured by the level of illiteracy). 
Together with the trust in others variable, a measure of social capital, equation (3) posits that prosperity depends on four kinds of capital—physical, human, social, and public. ${ }^{23}$

The system now becomes:

(1) $\mathrm{TC}=\mathrm{TC}(\mathrm{G}, \mathrm{TW}, \mathrm{ZTC})$

(2) $\mathrm{G}=\mathrm{G}(\mathrm{Y}, \mathrm{TC}, \mathrm{ZG})$

(3) $Y=Y\left(G, G^{2}, T O, Z Y\right)$

Model 2 of Table 3 describes the results of the three-stage-least squares estimation of this system of three equations. The estimated equation for income is quite reasonable. More physical capital and more human capital significantly increase real income per capita. So does more trust in others, although the coefficient only barely exceeds its estimated standard error. To put the magnitudes in perspective, a one standard deviation increase in trust in others is associated with a 5.5\% higher level of per capita income. The pattern of influence of government on prosperity takes the form suggested by Barro (1991a): its marginal effect is positive until a turning point is reached. The turning point is estimated to be at a government that represents $37.9 \%$ of GDP. Note, though, that the t-statistics are only slightly above one. ${ }^{24}$

One consequence of expanding the system to three equations is that, compared to Model 1, the coefficient on tax cheating in the size of government equation essentially goes to zero, and the absolute size and significance of the other variables declines, although the qualitative results are unchanged.

Finally, in Model 3 I show the results of replicating Model 2, but replacing the survey measure of trust with the survey measure of trustworthiness as a determinant of prosperity. According to this specification, trustworthiness cannot explain variations in prosperity as well as variations in trust can. However, this change sharpens the evidence for most of the other hypotheses I am concerned with. In particular, the negative coefficient of tax cheating on the size of government is restored, and the first-positive,

\footnotetext{
${ }^{23}$ Lack of data does not allow also including a measure of natural resources, or capital.

${ }^{24}$ Joint tests were performed on G and G-squared in Models 2 and 3 to test the hypothesis that government spending affects prosperity. In both tests the chi-squared statistic with 2 degrees of freedom fails to reach standard levels of significance.
} 
then-negative effect of government on prosperity becomes more statistically significant (with a turning point of $31.5 \%$ ). This illustrates the fragility of at least some of the conclusions that can be drawn from these exercises.

\subsection{Is It All Just Well-Tossed Spaghetti?}

Even without considering trust in government, Robert Putnam despaired that "the causal arrows among civic involvement, reciprocity, honesty, and social trust are as tangled as well-tossed spaghetti." (2000, p. 137) ${ }^{25}$ Clearly there are plausible stories that, of trust, trustworthiness, attitudes toward tax evasion, size of government, and prosperity, almost any variable has a direct effect on almost any other variable. Of course, to an econometrician, a bowl of spaghetti-like causal arrows raises issues of simultaneity bias, which require defensible "exclusion restrictions" to assert that the estimated coefficient reflect true causal, structural effects. The specifications I have investigated in this paper are based on a careful reading of the existing literature and introspection about, to put it directly, what affects what. In the process of this research I have learned that many of the findings are not robust to alternative, reasonable, specifications. Some are apparently more robust than others, as I suggest below. Nor have I even waded into the issues of data reliability, which are serious issues both with respect to the survey-based measures of trust and trustworthiness, but also to the measure of government size and other variables. Nevertheless, I believe that empirical analysis that simply ignores the interrelationships may be seriously misleading and an important research challenge is to try to untangle the well-tossed spaghetti. I summarize the insights from this exercise below.

I find some evidence that both prosperity and government involvement are higher in more trusting societies. Moreover, holding these measures of trust constant, the association of government size with prosperity is positive until a level of government spending somewhere between $31.5 \%$ and $37.9 \%$ of GDP, after which its marginal effect is negative.

There is a caveat to this neat story, however. In countries with bigger governments, there is a breakdown in the trustworthiness its citizens exhibit toward

\footnotetext{
${ }^{25}$ In a similar vein, Messere (1993) characterizes as "fishing expeditions" efforts to relate tax levels and structure to measures of economic performance.
} 
government, as measured by the acceptability of tax evasion. Thus, although a trusting citizenry allows larger government, the tax burden this entails erodes the rule obedience taxpayers exhibit toward government. Whether this is the reason that at some high level further government is associated with less prosperity is an intriguing, but still open, question.

\section{Conclusion: Trust in Public Finance}

Not surprisingly, these empirical exercises have uncovered neither the elixir of prosperity, nor the key to establishing trust among all mankind. Nor have they established that considering trust, social capital, and community constructs the conceptual bridge between government expenditure and taxation that Professor Musgrave despaired that the profession was overlooking.

Even if it were clear that taxpaying behavior depended on attitudes toward government, the policy implications are not clear. To be sure, these attitudes cannot be easily changed. Blumenthal, Christian, and Slemrod (2001) reports on the results of a field experiment in which Minnesota taxpayers were sent one of two letters, one that detailed the good things that taxes supported (without invoking the free-rider problem), and the other reporting the high rate of aggregate taxpayer compliance (playing down the "sucker" syndrome). Taxpayers who received either letter exhibited no significant increase in income tax compliance compared to a control group of taxpayers that did not receive either letter. Apparently one-shot exhortations are not successful, a result that wouldn't surprise many who are familiar with the marketing literature on this subject. ${ }^{26}$

One fascinating area for future research is whether our models of the behavioral response to the tax system fail when the free-rider assumption fails. To put the question starkly, can social capital explain why people continue to work, save and invest in the face of the high marginal tax rates in many countries? When social security benefits are tied to payroll tax payments via a formula, economists (e.g., Feldstein and Samwick (1992)) have questioned whether the incentive effects need to be adjusted for the marginal benefits that accrue. More generally, if for most taxpayers their tax payments

\footnotetext{
${ }^{26}$ There is, though, a school of marketing science experts who argue that one-shot advertising is nearly as effective as multiple communications.
} 
are the optimal Allingham-Sandmo payment plus a "gift" to government, will they respond to taxes as our standard model suggests?

I don't know the answer to this question, but I do know that is one aspect of a fundamental methodological question: is the positive theory of taxation a straightforward application of price theory, or is it something quite different? Consider the taxaugmented relative price term that applies to a commodity in an individual's budget set, $p^{*}(1+t)$, where the " $t$ " is the tax wedge inserted by a consumption tax or an income tax (in the latter case the relative price is usually written as $\mathrm{w}^{*}(1-\mathrm{t})$, where $\mathrm{w}$ is the wage rate). Using this notation, the methodological question is whether individuals respond to the relative price $p^{*}(1+t)$, or whether the response to the " $p$ " part and the " $(1+t)$ " part are systematically different. In the standard model they are not.

I have argued elsewhere (Slemrod, 2001) that because of avoidance and evasion, the response to $\mathrm{p}$ and the response to $(1+\mathrm{t})$ will be different. The idea is that a change in $\mathrm{t}$ changes the return-risk tradeoff of avoidance and evasion in ways that changes in $\mathrm{p}$ do not, and the former involves the tax avoidance technology and not only taxpayer preferences. The ideas explored in this paper suggest another reason why the two responses may be systematically different. ${ }^{27}$ Taxpayers' attitudes toward government affect how they react to $(1+\mathrm{t})$, but not to $\mathrm{p}$.

I am sure that Professor Musgrave would agree that public finance is much, much more than applied price theory. Indeed, he has written that his fascination with the field is "rooted in its broad scope, a joining of economics, politics, and social ethics," and that "the existence of externalities and the need to confront the issues of distribution enrich social life, the challenge of freedom and with it the human status of its members" (Buchanan and Musgrave, p. 29 and 49). No one has more eloquently stated the task before scholars of the public sector.

\footnotetext{
${ }^{27}$ Rosen (1976) and Konig, et al (1995) explore yet another reason, that taxpayers are unaware of their tax rate.
} 


\section{$\underline{\text { References }}$}

Allingham, M.G., and A. Sandmo. "Income Tax Evasion: A Theoretical Analysis." Journal of Public Economics 1: 323-38.

Alm, J., B. Jackson, and M. McKee. 1992. "Estimating the Determinants of Taxpayer Compliance with Experimental Data." National Tax Journal 45: 107-14.

Almond, G., and S. Verba. 1963. The Civic Culture. Princeton: Princeton University Press, 1963.

Andreoni, J., B. Erard, and J. Feinstein. 1998. “Tax Compliance.” Journal of Economic Literature 36, no. 2: 818-860.

Arrow, K. 1972. "Gifts and Exchanges." Philosophy and Public Affairs 1, no. 4: 343-67.

Associated Press. 2000. "Taxpayers Return Their Rebates to Help Pennsylvania's Schools," November 25.

Axelrod, R. 1986. "An Evolutionary Approach to Norms." American Political Science Review 80, no. 4: 1095-1111.

Barro, R.J. 1991. "A Cross-Country Study of Growth, Saving, and Government." National Saving and Economic Performance, eds. B. D. Bernheim and J. B. Shoven. Chicago: University of Chicago Press.

and D. B. Gordon. 1983. "Rules, Discretion and Reputation in a Model of Monetary Policy.” Journal of Monetary Economics 12, no. 1 (July): 101-21.

and X. Sala-i-Martin. 1992. "Public Finance in Models of Economic Growth." Review of Economic Studies 59, no. 4: 645-61.

Blumenthal, M., C. Christian, and J. Slemrod. 2001. "Do Normative Appeals Affect Tax Compliance? Evidence From a Controlled Experiment in Minnesota." National Tax Journal 54, no. 1: 125-38.

Bordignon, M. 1993. "A Fairness Approach to Income Tax Evasion." Journal of Public Economics 52, no. 3: 345-62. 
Brehm, J. 1998. Who Do You Trust? People, Government, or Neither? Duke University, Durham, North Carolina. Mimeographed.

Brehm, J., and W. Rahn. 1997. "Individual Level Evidence for the Causes and Consequences of Social Capital." American Journal of Political Science 41: 999-1023.

Buchanan, J. M., and R. A. Musgrave. 1999. Public Finance and Public Choice: Two Contrasting Visions of the State. Cambridge, Massachusetts: MIT Press.

Cameron, D.R. 1978. "The Expansion of the Public Economy; A Comparative Analysis." American Political Science Review 72, no. 4: 1243-61.

Campbell, D. E. 1995. Incentives: Motivation and the Economics of Information. New York: Cambridge University Press.

Clague, C. 1993. "Rule Obedience, Organizational Loyalty, and Economic Development." Journal of Institutional and Theoretical Economics 149, no. 2: 393-414.

Clotfelter, C. 1985. Federal Tax Policy and Charitable Giving. Chicago: University of Chicago Press.

Coleman, J. 1990. Foundations of Social Theory. Cambridge, Massachusetts: Harvard University Press.

Cowell, F. 1990. Cheating the Government. Cambridge, Massachusetts: MIT Press.

Cripps, M. W., and J. P. Thomas. 1995. "Reputation and Commitment in Two-Person Repeated Games without Discounting." Econometrica 63, no. 6: 1401-19.

Cullis, J. G., and A. Lewis. 1997. "Why People Pay Taxes: From a Conventional Economic Model to a Model of Social Convention." Journal of Economic Psychology 18, no. 2-3: 305-21.

Daunton, M. 1998. "Trusting Leviathan: British Fiscal Administration from the Napoleonic Wars to the Second World War." In Trust and Governance, eds. M. Levi and V. Braithwaite. New York: Russell Sage Foundation.

Easterly, W., and S. Rebelo. 1994. "Fiscal Policy and Economic Growth: An Empirical Investigation." Journal of Monetary Economics 32, no. 3: 417-58.

Epple, Dennis. 1998. "Rent Control with Reputation: Theory and Evidence," Regional Science and Urban Economics 28, no. 6: 679-710.

Falkinger, J. 1995. "Tax Evasion, Consumption of Public Goods, and Fairness," Journal of Economic Psychology 16, no. 1: 63-72. 
Feld, L. and B. Frey. In press. "Trust Breeds Trust: How Taxpayers Are Treated." Economics of Governance.

Feldstein, M., and A. Samwick. 1992. "Social Security Rules and Marginal Tax Rates." National Tax Journal 45, no. 1 (March): 1-22.

Frey, B. 1997. "A Constitution for Knaves Crowds Out Civic Virtues." Economic Journal 107: 1043-53.

Fukuyama, F. 1995. Trust. New York: Basic Books.

Glaeser, E. L., D. Laibson, J. A. Scheinkman, and C. L. Soutter. 1999. "Measuring Trust." Quarterly Journal of Economics 65: 811-46.

Goode, R. 1968. "The Tax Burden in the United States and Other Countries." Annals of the American Academy of Political and Social Science 379: 83-9.

Inglehart, R., M. Basanez and A. Moreno. Human Values and Beliefs: A CrossCultural Sourcebook. Ann Arbor: University of Michigan Press, 1998.

International Monetary Fund. 1994. Government Finance Statistics Yearbook. Washington: International Monetary Fund.

Johnston, D. C. "United Way, Faced With Fewer Donors, Is Giving Away Less." The New York Times, 9 November 1997.

Kahneman, D, J. L. Knetsch and R. Thaler. 1986. "Fairness and the Assumptions of Economics." Journal of Business 59, no. 4: S285-300.

Kaplan, S. E., and P. M. J. Reckers. 1985. "A Study of Tax Evasion Judgments." National Tax Journal 38, no. 1 (March): 97-102.

Klepper, S., and D. Nagin. 1989. "The Anatomy of Tax Evasion." Journal of Law, Economics, and Organization 5, no. 1: 1-24.

Knack, S., and P. Keefer. 1997. "Does Social Capital Have an Economic Payoff? A Cross-Country Investigation." Quarterly Journal of Economics 112, no. 4 (November): 1251-88.

Konig, H., F. Laisney, M. Lechner, and W. Pohlmeier. 1995. "Tax Illusion and the Labor Supply of Married Women: Evidence from German Data." Kyklos 48, no. 3: 34768.

La Porta, R, F. Lopez-de-Silanes, A. Shleifer, and R. Vishny. 1999. "The Quality of Government." Journal of Law, Economics, and Organization 15, no. 1: 222-79. 
Levi, M. 1998. "A State of Trust." In Trust and Governance, eds. M. Levi and V. Braithwaite. New York: Russell Sage Foundation.

Levine, R., and D. Renelt. 1992. "A Sensitivity Analysis of Cross-Country Growth Regressions." American Economic Review 82, no. 4: 942-63.

Marks, M. B., and E. D. Schansberg. 1997. "Fairness and Reputation Effects in a Provision Point Contributions Process." Nonprofit Management and Leadership, 235-51.

Mason, R. and L. D. Calvin. 1984. "Public Confidence and Admitted Tax Evasion." National Tax Journal 37, no. 4 (December): 489-96.

Messere, K. C. 1993. Tax Policy in OECD Countries: Choices and Conflicts. Amsterdam: IBFD Publications BV.

Musgrave, R. A. 1969. Fiscal Systems. New Haven: Yale University Press.

Musgrave, R. A., and P. B. Musgrave. 1989. Public Finance in Theory and Practice. 5th ed. New York: McGraw-Hill Book Co.

Newton, K. 1999. "Social and Political Trust in Established Democracies." In Critical Citizens: Global Support for Democratic Government, ed. P. Norris. Oxford: Oxford University Press, 1999.

Ostrom, E. 2000. "Collective Action and the Evolution of Social Norms." Journal of Economic Perspectives 14, no. 3 (Summer): 137-58.

Putnam, R. 2000. Bowling Alone. New York: Simon \& Schuster.

Putnam, R. (with R. Leonardi and R. Y. Nanetti). 1993. Making Democracy Work. Princeton: Princeton University Press.

Rodrik, D. 1998. “Why Do More Open Economies have Bigger Governments?” Journal of Political Economy. 106, no. 5: 997-1032.

Rosen, H.S. 1976. "Tax Illusion and the Labor Supply of Married Women." The Review of Economics and Statistics 58, no. 2: 167-72.

Roth, J. A., J. T. Scholz, and A. D. Witte, eds. 1989. Taxpayer Compliance Vol. 1. An Agenda for Research. Philadelphia: University of Pennsylvania Press.

Sandel, M. J. 1998. Democracy's Discontent: America in Search of a Public Philosophy, Cambridge, Massachusetts and London: Belknap Press of Harvard University Press. 
Scholz, J. T., and M. Lubell. 1998a. "Trust and Taxpayers: Testing the Heuristic Approach to Collective Action." American Journal of Political Science 42, no. 2 (April): 398-417.

Scholz, J. T., and M. Lubell. 1998b. “Adaptive Political Attitudes: Duty, Trust, and Fear as Monitors of Tax Policy.” American Journal of Political Science 42: 903-20.

Scholz, J. T., and M. Lubell. 2001. "Cooperation, Reciprocity, and the Collective Action Heuristic." American Journal of Political Science 45: 160-78.

Slemrod, J. 2001. "A General Model of the Behavioral Response to Taxation." International Tax and Public Finance.

. 1995. "What Do Cross-Country Studies Teach About Taxes, Prosperity, and Economic Growth?" Brookings Papers on Economic Activity 2: 373-415.

and E. Oltmans. 2000. Gifts to Government. University of Michigan, Ann Arbor, Michigan. Mimeographed.

Spicer, M. W., and L. A. Becker. 1976. "Fiscal Inequity and Tax Evasion: An Experimental Approach." National Tax Journal 33, no. 2 (June): 171-5.

Steuerle, C. E. 1986. Who Should Pay for Collecting Taxes? Financing the IRS. Washington, D.C.: American Enterprise Institute.

Summers, R. and A. Heston. "The Penn World Table (Mark 5): An Expanded Set of International Comparisons, 1950-1988." Quarterly Journal of Economics 106, no. 2: 32768.

Tanzi, V. 1992. "Structural Factors and Tax Revenue in Developing Countries: A Decade of Evidence." In Open Economies: Structural Adjustment and Agriculture, eds. I. Goldin and L.A. Winters. Cambridge: Cambridge University Press.

Taylor, M. 1982. Community, Anarchy, and Liberty. Cambridge: Cambridge University Press.

Zak, P. and S. Knack. 2001. “Trust and Growth.” Economic Journal 111 (April): 295321. 
Table 1 -- Within Country Correlations for USA and West Germany

\begin{tabular}{|c|c|c|c|c|c|c|c|c|c|c|c|c|}
\hline & {$[1]$} & [2] & [3] & [4] & [5] & [6] & [7] & {$[8]$} & [9] & [10] & [11] & [12] \\
\hline & Age & $\begin{array}{l}\text { Acceptability of } \\
\text { Tax Evasion }\end{array}$ & $\begin{array}{c}\text { Confidence } \\
\text { in Gov't } \\
\text { Institutions }\end{array}$ & Education & $\begin{array}{c}\text { Financial } \\
\text { Satisfaction }\end{array}$ & $\begin{array}{l}\text { Income } \\
\text { Scale }\end{array}$ & Male & $\begin{array}{l}\text { Non- } \\
\text { religious }\end{array}$ & $\begin{array}{c}\text { Right } \\
\text { Political } \\
\text { Orientation }\end{array}$ & $\begin{array}{l}\text { Trust in } \\
\text { Others }\end{array}$ & $\begin{array}{c}\text { Trust in } \\
\text { Gov't }\end{array}$ & $\begin{array}{c}\text { Trust- } \\
\text { worthiness }\end{array}$ \\
\hline [1] Age & $\begin{array}{l}1.000 \\
1.000\end{array}$ & & & & & & & & & & & \\
\hline $\begin{array}{l}\text { [2] Acceptability of } \\
\text { Tax Evasion }\end{array}$ & $\begin{array}{l}-0.192^{\star \star \star} \\
-0.221^{\star \star \star}\end{array}$ & $\begin{array}{l}1.000 \\
1.000\end{array}$ & & & & & & & & & & \\
\hline $\begin{array}{l}\text { [3] Confidence in } \\
\text { Gov't Institutions }\end{array}$ & $\begin{array}{l}0.053^{\star \star} \\
0.190^{\star \star \star}\end{array}$ & $\begin{array}{l}-0.051^{\star \star} \\
-0.249^{\star \star \star \star}\end{array}$ & $\begin{array}{l}1.000 \\
1.000\end{array}$ & & & & & & & & & \\
\hline [4] Education & $\begin{array}{l}-0.222^{\star \star \star} \\
-0.341^{\star \star \star}\end{array}$ & $\begin{array}{l}0.0021 \\
0.138^{\star \star \star}\end{array}$ & $\begin{array}{l}-0.059^{\star \star} \\
-0.118^{\star \star \star}\end{array}$ & $\begin{array}{l}1.000 \\
1.000\end{array}$ & & & & & & & & \\
\hline $\begin{array}{l}\text { [5] Financial } \\
\text { Satisfaction }\end{array}$ & $\begin{array}{l}0.204^{\star \star \star} \\
0.166^{\star \star \star}\end{array}$ & $\begin{array}{l}-0.085^{\star \star \star \star} \\
-0.146^{\star \star \star}\end{array}$ & $\begin{array}{l}0.087^{\star \star \star} \\
0.238^{\star \star \star}\end{array}$ & $\begin{array}{l}0.031 \\
0.002\end{array}$ & $\begin{array}{l}1.000 \\
1.000\end{array}$ & & & & & & & \\
\hline [6] Income Scale & $\begin{array}{l}-0.170^{\star \star \star} \\
-0.249^{\star \star \star}\end{array}$ & $\begin{array}{l}0.019 \\
0.071^{\star \star \star}\end{array}$ & $\begin{array}{r}-0.038 \\
0.022\end{array}$ & $\begin{array}{l}0.340^{\star \star \star} \\
0.278^{\star \star \star}\end{array}$ & $\begin{array}{l}0.246^{\star \star \star} \\
0.250^{\star \star \star}\end{array}$ & $\begin{array}{l}1.000 \\
1.000\end{array}$ & & & & & & \\
\hline [7] Male & $\begin{array}{l}0.029 \\
-0.118^{\star \star *}\end{array}$ & $\begin{array}{l}0.024 \\
0.118^{\star \star \star}\end{array}$ & $\begin{array}{l}-0.034 \\
-0.046^{\star \star}\end{array}$ & $\begin{array}{l}0.071^{\star \star \star} \\
0.082^{\star \star \star}\end{array}$ & $\begin{array}{l}0.067^{\star \star *} \\
0.0027\end{array}$ & $\begin{array}{l}0.086^{\star \star \star} \\
0.095^{\star \star \star}\end{array}$ & $\begin{array}{l}1.000 \\
1.000\end{array}$ & & & & & \\
\hline [8] Nonreligious & $\begin{array}{l}-0.121^{\star \star \star} \\
-0.259^{\star \star \star}\end{array}$ & $\begin{array}{l}0.137^{\star \star \star} \\
0.266^{\star \star \star}\end{array}$ & $\begin{array}{l}-0.051^{\star \star} \\
-0.174^{\star \star \star}\end{array}$ & $\begin{array}{l}0.049^{*} \\
0.142^{\star \star \star}\end{array}$ & $\begin{array}{l}-0.067^{\star \star \star} \\
-0.176^{\star \star \star}\end{array}$ & $\begin{array}{l}0.044^{*} \\
0.029\end{array}$ & $\begin{array}{l}0.084^{\star \star \star} \\
0.159^{\star \star \star}\end{array}$ & $\begin{array}{l}1.000 \\
1.000\end{array}$ & & & & \\
\hline $\begin{array}{l}\text { [9] Right Political } \\
\text { Orientation }\end{array}$ & $\begin{array}{l}0.058^{\star \star} \\
0.236^{\star \star \star}\end{array}$ & $\begin{array}{l}-0.031 \\
-0.142^{\star \star \star}\end{array}$ & $\begin{array}{l}0.082^{\star \star \star} \\
0.240^{\star \star \star}\end{array}$ & $\begin{array}{l}-0.032 \\
-0.110^{\star \star \star}\end{array}$ & $\begin{array}{l}0.116^{\star \star \star} \\
0.182^{\star \star \star}\end{array}$ & $\begin{array}{l}0.025 \\
0.049^{\text {*ᄎ }}\end{array}$ & $\begin{array}{l}\mathbf{0 . 0 6 2 ^ { \star * }} \\
0.0172\end{array}$ & $\begin{array}{l}-0.173^{\star \star *} \\
-0.245^{\star \star \star}\end{array}$ & $\begin{array}{l}1.000 \\
1.000\end{array}$ & & & \\
\hline [10] Trust in Others & $\begin{array}{l}0.105^{\star \star \star} \\
-0.047^{\star}\end{array}$ & $\begin{array}{l}-0.115^{\star \star \star} \\
-0.0327\end{array}$ & $\begin{array}{l}-0.017 \\
0.098^{\star \star *}\end{array}$ & $\begin{array}{l}0.148^{\star \star \star *} \\
0.143^{\star \star \star}\end{array}$ & $\begin{array}{l}0.104^{\star \star \star} \\
0.123^{\star \star \star}\end{array}$ & $\begin{array}{l}0.099^{\star \star \star} \\
0.098^{\star \star \star}\end{array}$ & $\begin{array}{c}-0.019 \\
0.0006\end{array}$ & $\begin{array}{l}-0.053^{\star *} \\
-0.0235\end{array}$ & $\begin{array}{l}-0.076^{* * *} \\
-0.0184\end{array}$ & $\begin{array}{l}1.000 \\
1.000\end{array}$ & & \\
\hline [11] Trust in Gov't & 0.001 & $-0.099^{\star * *}$ & $0.106^{\star \star *}$ & 0.040 & $0.129^{\star \star \star *}$ & 0.032 & $-0.060^{\star \star}$ & $-0.092^{\star \star \star}$ & $0.066^{\star \star \star}$ & $0.093^{\star \star \star}$ & 1.000 & \\
\hline $\begin{array}{l}\text { [12] Trust- } \\
\text { worthiness }\end{array}$ & $\begin{array}{l}0.149^{\star \star \star \star} \\
0.249^{\star \star \star}\end{array}$ & $\begin{array}{l}-0.383^{\star \star \star} \\
-0.505^{\star \star \star}\end{array}$ & $\begin{array}{l}0.066^{\star \star \star \star} \\
0.172^{\star \star \star}\end{array}$ & $\begin{array}{l}-0.065^{\star \star \star} \\
-0.084^{\star \star \star}\end{array}$ & $\begin{array}{l}0.063^{\star \star \star} \\
0.123^{\star \star \star}\end{array}$ & $\begin{array}{l}-0.054^{\star \star} \\
-0.083^{\star \star \star}\end{array}$ & $\begin{array}{l}-0.021 \\
-0.085^{\star \star \star}\end{array}$ & $\begin{array}{l}-0.122^{\star \star \star} \\
-0.274^{\star \star \star}\end{array}$ & $\begin{array}{l}0.027 \\
0.121^{\star \star \star}\end{array}$ & $\begin{array}{l}0.097^{\star \star \star} \\
0.063^{\star \star}\end{array}$ & $0.041^{*}$ & 1.000 \\
\hline
\end{tabular}


Table 2 -- Cross-Country Correlations

\begin{tabular}{|c|c|c|c|c|c|c|c|c|c|c|c|c|c|}
\hline & {$[1]$} & [2] & [3] & [4] & [5] & {$[6]$} & [7] & [8] & [9] & {$[10]$} & [11] & [12] & {$[13]$} \\
\hline & Agriculture & $\begin{array}{l}\text { Cheating } \\
\text { on Taxes }\end{array}$ & Education & $\begin{array}{c}\text { Financial } \\
\text { Satisfaction }\end{array}$ & $\begin{array}{c}\text { GDP per } \\
\text { Capita (log) }\end{array}$ & $\begin{array}{c}\text { Gov't } \\
\text { Expenditure } \\
\text { Ratio }\end{array}$ & Illiteracy & $\begin{array}{l}\text { Legal } \\
\text { Origin } \\
\text { EGS }\end{array}$ & $\begin{array}{l}\text { Non- } \\
\text { religious }\end{array}$ & Openness & $\begin{array}{c}\text { Right } \\
\text { Political } \\
\text { Orientation }\end{array}$ & $\begin{array}{l}\text { Trust in } \\
\text { Others }\end{array}$ & $\begin{array}{c}\text { Trust- } \\
\text { worthiness }\end{array}$ \\
\hline [1] Agriculture & 1.000 & & & & & & & & & & & & \\
\hline $\begin{array}{l}\text { [2] Cheating on } \\
\text { Taxes }\end{array}$ & $-0.434^{\star \star}$ & 1.000 & & & & & & & & & & & \\
\hline [3] Education & $-0.516^{\star *}$ & 0.119 & 1.000 & & & & & & & & & & \\
\hline $\begin{array}{l}\text { [4] Financial } \\
\text { Satisfaction }\end{array}$ & $-0.512^{\star \star \star}$ & $0.386^{*}$ & $0.474^{\star \star}$ & 1.000 & & & & & & & & & \\
\hline $\begin{array}{l}\text { [5] GDP per } \\
\text { Capita (log) }\end{array}$ & $-0.877^{\star \star \star}$ & $0.388^{\star}$ & $0.654^{\star \star \star}$ & $0.658^{\star \star \star}$ & 1.000 & & & & & & & & \\
\hline $\begin{array}{l}\text { [6] Government } \\
\text { Expenditure }\end{array}$ & $-0.465^{\star \star}$ & $0.515^{\star \star *}$ & 0.296 & $0.720^{\star \star \star}$ & $0.618^{\star \star \star}$ & 1.000 & & & & & & & \\
\hline [7] Illiteracy & $0.914^{\star \star \star}$ & -0.316 & $-0.646^{\star \star \star}$ & $-0.452^{\star \star}$ & $-0.884^{\star \star \star}$ & $-0.418^{\star *}$ & 1.000 & & & & & & \\
\hline $\begin{array}{l}\text { [8] Legal Origin } \\
\text { EGS }\end{array}$ & -0.026 & -0.266 & $0.460^{\star *}$ & 0.311 & 0.298 & 0.124 & -0.120 & 1.000 & & & & & \\
\hline [9] Nonreligious & $-0.390^{\star}$ & 0.128 & $0.415^{\star \star}$ & 0.025 & $0.383^{\star}$ & 0.090 & $-0.349^{*}$ & 0.138 & 1.000 & & & & \\
\hline [10] Openness & -0.278 & $0.525^{\star \star \star}$ & 0.208 & $0.475^{\star \star}$ & 0.310 & $0.446^{* *}$ & $-0.346^{\star}$ & -0.034 & 0.008 & 1.000 & & & \\
\hline $\begin{array}{l}\text { [11] Right Political } \\
\text { Orientation }\end{array}$ & 0.044 & -0.126 & $0.420^{\star \star}$ & 0.002 & 0.052 & -0.240 & -0.060 & $0.619^{* \star \star}$ & 0.049 & 0.184 & 1.000 & & \\
\hline $\begin{array}{l}\text { [12] Trust in } \\
\text { Others }\end{array}$ & $-0.348^{\star}$ & 0.201 & $0.692^{\star \star \star}$ & $0.651^{\star \star \star}$ & $0.553^{\star * \star}$ & $0.564^{\star \star \star}$ & $-0.393^{\star}$ & $0.618^{\star \star \star}$ & 0.326 & 0.180 & 0.284 & 1.000 & \\
\hline [13] Trustworthiness & 0.292 & $-0.697^{\star \star \star}$ & 0.231 & -0.124 & -0.121 & -0.123 & 0.073 & $0.496^{\star \star \star}$ & -0.012 & -0.244 & 0.202 & 0.261 & 1.000 \\
\hline
\end{tabular}

NOTES: * significant at $10 \%$ level; ** significant at $5 \%$ level; ${ }^{\star \star *}$ significant at $1 \%$ level; all correlation coefficients are computed from 25 data points. 
Table 3 - Results of 3SLS Estimation of Structural Models

\begin{tabular}{|c|c|c|c|c|c|c|c|c|}
\hline \multirow[b]{2}{*}{ Independent/Dependent Variables } & \multicolumn{2}{|c|}{ Model 1} & \multicolumn{3}{|c|}{ Model 2} & \multicolumn{3}{|c|}{ Model 3} \\
\hline & Cheat on Tax & G/GDP & Cheat on Tax & G/GDP & GDP P.C $(\log )$ & Cheat. on Tax & G/GDP & GDP P.C $(\log )$ \\
\hline Cheating on Taxes & & $\begin{array}{l}-1.099 \\
-0.832\end{array}$ & & $\begin{array}{l}-0.046 \\
-0.593\end{array}$ & & & $\begin{array}{c}-1.18 \\
(-0.864)\end{array}$ & \\
\hline G/GDP & $\begin{array}{l}0.405 \\
(0.116)^{\star * *}\end{array}$ & & $\begin{array}{c}0.396 \\
(0.101)^{\star \star *}\end{array}$ & & $\begin{array}{c}0.0255 \\
(0.0211)\end{array}$ & $\begin{array}{c}0.387 \\
(0.130)^{\star \star \star}\end{array}$ & & $\begin{array}{c}0.0255 \\
(0.0250)\end{array}$ \\
\hline$(G / G D P)^{\wedge} 2$ & & & & & $\begin{array}{l}-0.000336 \\
(0.000295)\end{array}$ & & & $\begin{array}{l}-0.000405 \\
(0.000357)\end{array}$ \\
\hline GDP Per Capita (log) & & $\begin{array}{l}43.5 \\
(15.4)^{\star \star \star}\end{array}$ & & $\begin{array}{l}35.2 \\
(16.1)^{\star \star \star}\end{array}$ & & & $\begin{array}{l}51.7 \\
(20.8)^{\star \star}\end{array}$ & \\
\hline Age & $\begin{array}{l}-0.686 \\
(0.426)\end{array}$ & & $\begin{array}{l}-0.584 \\
(0.392)\end{array}$ & & & $\begin{array}{l}-0.640 \\
(0.447)\end{array}$ & & \\
\hline Age Dependency Ratio & & $\begin{array}{c}0.607 \\
(0.575)\end{array}$ & & $\begin{array}{c}0.233 \\
(0.468)\end{array}$ & & & $\begin{array}{c}0.713 \\
(0.631)\end{array}$ & \\
\hline Agriculture/GDP & & $\begin{array}{l}-0.898 \\
(1.298)\end{array}$ & & $\begin{array}{l}0.0472 \\
(1.03)\end{array}$ & & & $\begin{array}{l}-0.582 \\
(1.39)\end{array}$ & \\
\hline Illiteracy & & $\begin{array}{c}1.83 \\
(0.865)^{\star \star}\end{array}$ & & $\begin{array}{l}1.21 \\
(0.712)^{*}\end{array}$ & $\begin{array}{l}-0.0149 \\
(0.00634)^{\star *}\end{array}$ & & $\begin{array}{l}2.003 \\
(0.947)^{\star \star}\end{array}$ & $\begin{array}{l}-0.00977 \\
(0.00768)\end{array}$ \\
\hline Legal Origin EGS & & $\begin{array}{l}-10.2 \\
(7.33)\end{array}$ & & $\begin{array}{l}-5.15 \\
(6.50)\end{array}$ & & & $\begin{array}{r}-12.96 \\
(8.43)\end{array}$ & \\
\hline Openness & & $\begin{array}{l}0.302 \\
(0.139)^{\star \star}\end{array}$ & & $\begin{array}{c}0.162 \\
(0.102)\end{array}$ & & & $\begin{array}{c}0.303 \\
(0.143)^{\star \star}\end{array}$ & \\
\hline Capital Per Worker (log) & & & & & $\begin{array}{l}0.557 \\
(0.113)^{\star \star \star}\end{array}$ & & & $\begin{array}{c}0.721 \\
(0.158)^{* * *}\end{array}$ \\
\hline Trust & & & & & $\begin{array}{r}0.00379 \\
(0.00329)\end{array}$ & & & \\
\hline Trustworthiness & $\begin{array}{l}-0.665 \\
(0.140)^{\star \star \star}\end{array}$ & & $\begin{array}{l}-0.654 \\
(0.135)^{\star \star \star}\end{array}$ & & & $\begin{array}{l}-0.671 \\
(0.140)^{\star \star \star}\end{array}$ & & $\begin{array}{c}0.00142 \\
(0.00507)\end{array}$ \\
\hline Constant & $\begin{array}{c}82.7 \\
(16.3)^{\star \star \star}\end{array}$ & $\begin{array}{l}-396.4 \\
(160.3)^{\star \star}\end{array}$ & $\begin{array}{l}77.97 \\
(15.7)^{\star * * *}\end{array}$ & $\begin{array}{l}-313.8 \\
(166.7)^{\star}\end{array}$ & $\begin{array}{l}3.29 \\
(1.16)^{* * \star}\end{array}$ & $\begin{array}{l}82.0 \\
(16.2)^{* * *}\end{array}$ & $\begin{array}{l}-479.1 \\
(215.2)^{\star \star}\end{array}$ & $\begin{array}{c}1.88 \\
(1.69)\end{array}$ \\
\hline $\begin{array}{l}\text { Number of Observations } \\
\text { Chi-squared test }\end{array}$ & $\begin{array}{c}25 \\
50.9^{* \star *}\end{array}$ & $\begin{array}{c}25 \\
23.7^{\star \star \star}\end{array}$ & $\begin{array}{c}25 \\
54.4^{* \star \star}\end{array}$ & $\begin{array}{c}25 \\
29.8^{\star \star \star}\end{array}$ & $\begin{array}{c}25 \\
371.7^{\star \star \star}\end{array}$ & 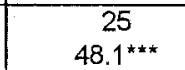 & $\begin{array}{c}25 \\
19.8^{\star * *}\end{array}$ & $\begin{array}{c}25 \\
296.2^{\star \star \star}\end{array}$ \\
\hline
\end{tabular}

NOTES: Standard errors in parenthesis; ${ }^{*}$ significant at $10 \%$ level; $_{*}^{* *}$ significant at $5 \%$ level $\left.\right|_{\xi} ^{* * *}$ significant at $10 \%$ level. 
Table 4 -- Cross-Country Summary Statistics

\begin{tabular}{|c|c|c|c|c|c|}
\hline Variable & $\begin{array}{c}\text { Number of } \\
\text { Observations }\end{array}$ & Mean & $\begin{array}{l}\text { Standard } \\
\text { Deviation }\end{array}$ & Minimum & Maximum \\
\hline Agriculture & 25 & 6.340 & 6.332 & 1.825 & 30.766 \\
\hline GDP Per Capita (log) & 25 & 9.394 & 0.629 & 7.317 & 9.990 \\
\hline Government Expenditure & 25 & 40.846 & 14.169 & 16.222 & 61.280 \\
\hline Government Expenditure Squared & 25 & 1861.161 & 1052.557 & 263.146 & 3755.248 \\
\hline Legal Origin EGS & 25 & 0.600 & 0.500 & 0 & 1 \\
\hline Openness & 25 & 59.089 & 30.695 & 15.180 & 144.960 \\
\hline Trust: & 25 & 40.206 & 14.617 & 9.980 & 66.102 \\
\hline Trustworthiness & 25 & 80.621 & 7.3517 & 64.008 & 91.507 \\
\hline
\end{tabular}


Table 5 - Within USA and West Germany Summary Statistics

USA

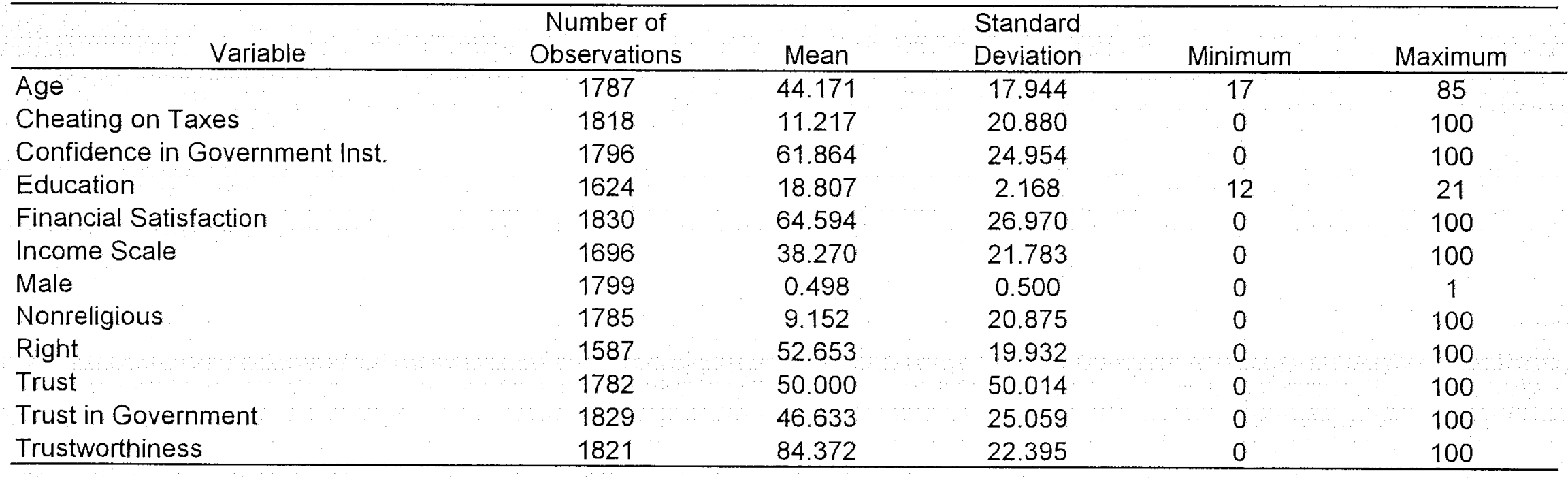

\section{West Germany}

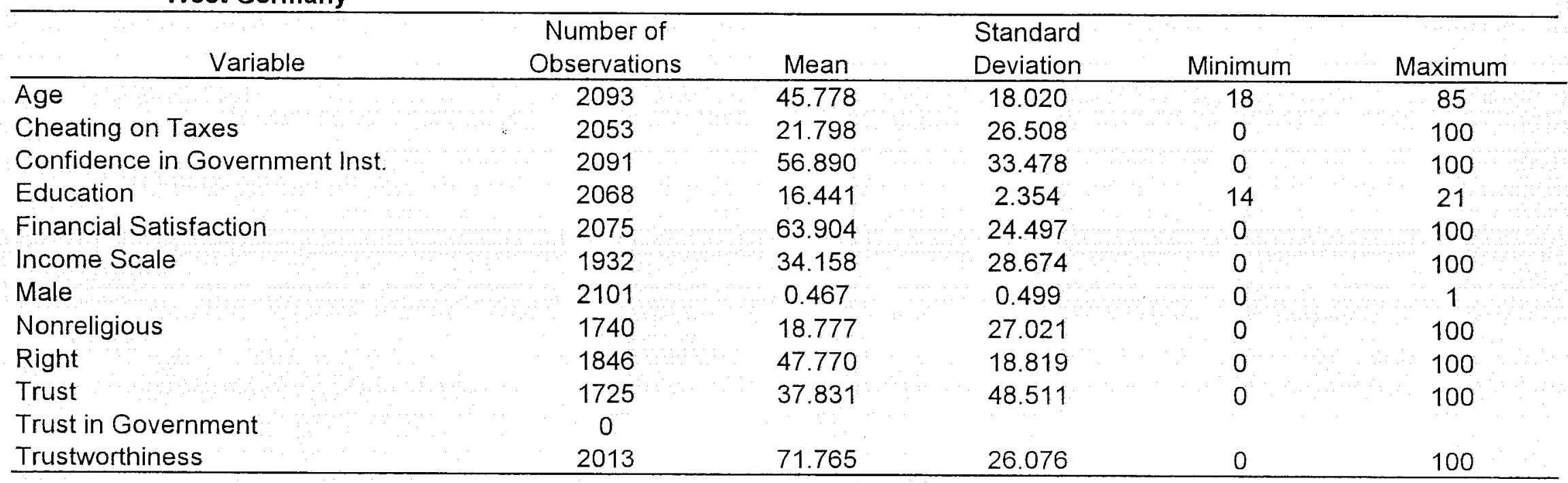

NOTES: All means and standard deviations are calculated using survey weights. 
DATA APPENDIX

Variable Description

Population (in '000s, 1990)

GDP per Capita (in 1990 PPP \$)

Capital Per Worker (in 1990 PPP \$)

Openness $=$ sum of imports and exports as a

proportion of GDP for 1990

Age Dependency Ratio = ratio of population under age 15 and above age 65 to the working-age population aged $15-64$ (in \%) in 1990

Illiteracy Rate $=$ number of people aged 15 and above who cannot, with understanding, read and write a short, simple statement of their everyday life as a proportion of total population (in \%) in 1990

Share of Agriculture in GDP = sum of value added from forestry, hunting, fishing, cultivation of crops and livestock production as a proportion of GDP (in \%) in 1990

Share of Consolidated Government Tax Expenditure in GDP = sum of consolidated central (C.II), state/ regional (St.C.II) and local (L.C.II) government expenditures, less transfers from all the three levels of government (T.I), as a proportion of GDP (in \%) in 1990

Legal Origin = legal origin of the Company Law or Commercial Code. There are four possible origins:

(1) English Common Law; (2) French Commercial Code; (3) German Commercial Code; and (4) Scandinavian Commercial Code "Legal Origin EGS" is one if English, German, or Scandinavian, and zero otherwise

Trust in Others $=$ weighted average (or individual level data for West Germany and USA), normalized to scale 0 to 100 , of survey responses to question:

"Generally speaking, would you say that most people can be trusted or that you can't be too careful in dealing with people?"

$(0=$ can't be too careful; $1=$ most people can be trusted)

Trust in Government $=$ weighted average (or individual level data for West Germany and USA), normalized to scale 0 to 100 , of survey responses
Source and Notes

PWT 5.6

PWT 5.6

PWT 5.6

PWT 5.6

WDI CD-ROM

WDI CD-ROM; based on information from WDR 1992. The missing values were filled in by zeroes for all countries with missing values except for Iceland and Ireland, for which 0 was substituted based on background information from CIA 2000 World Factbook

WDI CD-ROM; datum for West Germany taken from WDR 1992; datum for Switzerland taken from NAS 1994

GFSY 1995 and 1997 for Fiscal Data; WDI CD-ROM for GDP; GDP datum for Germany taken from NAS 1994; shares calculated in 1988 for Chile, 1989 for Italy and Japan and 1991 for Switzerland; missing data substituted for by zeroes

La Porta et al. (1999)

WVS 
to question: "How much do you trust the government in [national capital] to do what is right? Do you trust it almost always, most of the time, only some of the time, or almost never?"

$(1=$ almost never to $4=$ almost always $)$

Acceptability of Tax Evasion $=$ weighted average

WVS (or individual level data for West Germany and USA), normalized to scale 0 to 100 , of survey responses to question: "Please tell me whether you think cheating on tax if you have the chance can always be justified, never be justified, or something in between." (using scale from $1=$ never justified to $10=$ always justified)

Trustworthiness $=$ weighted average (or

WVS individual level data for West Germany and USA), normalized to scale 0 to 100 , of survey responses to question: "Please tell me whether you think lying in your own interest can always be justified, never be justified, or something in between." (using scale from $1=$ always justified to $10=$ never justified)

Confidence in Government Institutions = weighted

WVS average (or individual level data for West Germany and USA) of sum of total, divided by 4 , normalized to scale 0 to 100; of number of responses of "a great deal" or "quite a lot" to question: "Please look at this card and tell me, for each item listed, how much confidence you have in them. Is it a great deal, quite a lot, not very much or none at all?

(a) The education system

(b) The legal system

(c) The police

(d) The civil service"

Age = weighted average (or individual level data for WVS West Germany and USA) of survey respondent age in years

Education = individual level data for West Germany WVS and USA of survey responses to question: "At what age did you or will you complete your full time education, either at school or at an institution of higher education? Please exclude apprenticeships?"

(responses truncated at 12 years from below and at 21 years from above)

Financial Satisfaction = individual level data for West Germany and USA, normalized to scale 0 to 100 , of survey responses to question: "How 
satisfied are you with the financial situation of your household?"

(using scale from $1=$ dissatisfied to $10=$ satisfied)

Income Scale $=$ individual level data for West

WVS Germany and USA, normalized to scale 0 to 100 , of survey responses to question: "Here is a scale of incomes and we would like to know in what group your household is, counting all wages, salaries, pensions and other incomes that come in. Just give the letter of the group your household falls into, before taxes and other deductions."

(using nation-specific codes, $1=$ lowest, $10=$ highest)

Male $=$ individual level data indicator, for West WVS Germany and USA, for a survey respondent being male

Nonreligious $=$ individual level data for West WVS Germany and USA, normalized to scale 0 to 100 , of survey responses to question:

"Independently of whether you go to church or not, would you say that you are: $1=a$ religious person; 2 = not a religious person; $3=$ a convinced atheist."

Right Political Orientation = individual level data, WVS normalized to scale 0 to 100 , of survey responses to question: "In political matters, people talk of "the left" and "the right." How would you place your views on this scale, generally speaking?"

Key: PW.T 5.6 is from http://pwt.econ.upenn/edu, described in Summers, Robert and Alan Heston, "The Penn World Table (Mark 5): An Expanded Set of International Comparisons, 1980-1988," Quarterly Journal of Economics, May 1991.

WDI CD-ROM is World Development Indicators 2001 CD-ROM, World Bank, 2001, Washington, D.C.

WDR is World Development Report, World Bank, 1992, Washington, D.C.

ClA World Factbook is The World Factbook, Central Intelligence Agency, 2000, Washington, D.C., http://www.cia.gov/cia/publications/factbook.

NAS is National Accounts Statistics, United Nations, 1994, New York. 